\title{
FUNGSI SUNGAI BAGI MASYARAKAT DI TEPIAN SUNGAI KUIN KOTA BANJARMASIN
}

\section{Rochgiyanti $\bowtie$}

Program Studi Pendidikan Sosiologi FKIP Unlam, Banjarmasin, Indonesia

\section{Info Artikel}

\section{Sejarah Artikel:}

Diterima Desember 2010

Disetujui Januari 2011

Dipublikasikan Maret 2011

\section{Keywords:}

functions of river; economic interaction; socialization; transportation.

\begin{abstract}
Abstrak
Banjarmasin merupakan ibukota Provinsi Kalimantan Selatan yang dikenal sebagai kota seribu sungai. Kota ini bernama Banjarmasin karena kondisi geografisnya yang dikelilingi oleh sungai besar dan kecil. Salah satu sungai tersebut adalah sungai yang melewati wilayah Desa Kuin Kuin Utara, Selatan Kuin dan Kuin Cerucuk. Tujuan artikel ini adalah untuk membahas fungsi sungai bagi masyarakat yang tinggal di tepi Sungai Kuin Banjarmasin Kalimantan Selatan. Penulisan ini menggunakan metode deskriptif kualitatif. Data dikumpulkan melalui wawancara dan observasi. Hasil penelitian menunjukkan bahwa sungai tidak hanya berfungsi sebagai jalur transportasi, tetapi juga berfungsi untuk kegiatan ekonomi, interaksi, dan sosialisasi.
\end{abstract}

\begin{abstract}
Banjarmasin is the capital of South Kalimantan Province, which is also known as the city of a thousand rivers. The city is named Banjarmasin due to its geographical conditions which is surrounded by large and small rivers. One of the rivers is the Kuin river that passes through the village of Kuin, North and South Kuin and Kuin Cerucuk. The purpose of this article is to discuss the functions of the river for the people living on the banks of the River Kuin Banjarmasin South Kalimatan. The writing used descriptive qualitative method. Data were collected through interviews and observation. The results show that the river does not only serve as transportation routes, but also serves as economic activity, interaction, and socialization.
\end{abstract}

(C) 2011 Universitas Negeri Semarang

\footnotetext{
Alamat korespondensi:

Kampus FKIP Unlam Banjarmasin, Indonesia

E-mail: rochgiyanti@yahoo.com
} 


\section{PENDAHULUAN}

Kalimantan Selatan merupakan salah satu provinsi di Indonesia yang memiliki banyak sungai sebagai salah satu sumber daya alamnya. Sungai terbesar dan terpanjang di Kalimantan Selatan adalah Sungai Barito, yang mata airnya berasal dari pedalaman Kalimantan Tengah dan bermuara ke Laut Jawa. Sungai Barito mempunyai banyak anak sungai, dan wilayah di sepanjang aliran sungai ini sejak jaman dulu telah menjadi tempat konsentrasi pemukiman penduduk. Oleh karena itu, sejak dulu lokasi kota-kota banyak yang berada di sekitar muara sungai atau tepi pantai.

Daerah tepian sungai merupakan wilayah yang sangat subur karena endapan lumpur akibat pengaruh pasang surut air sungai. Oleh karena kesuburan tanahnya maka wilayah tepian sungai menjadi tempat konsentrasi penduduk. Disamping Sungai Barito dan anak-anak sungainya, juga banyak ditemukan sungai buatan atau kanal yang disebut anjir, handil, saka. Begitu pentingnya sungai bagi masyarakat Kalimantan Selatan sehingga berkembang suatu budaya sungai, yang berpengaruh pada hampir setiap kehidupan masyarakatnya.

Sesuai dengan kondisi geografisnya maka rumah-rumah penduduk dibangun di atas tiang-tiang di tepi sungai, atau di atas sungai. Rumah-rumah penduduk dibangun dari kayu hutan yang banyak terdapat di wilayah Kalimantan Selatan. Semula rumah-rumah dibangun di tepian sungai, menghadap ke arah sungai sehingga sungai menjadi halaman depan. Berbeda dengan sungai-sungai di pekotaan besar, di mana terdapat banyak kegiatan domestik masyarakat yang berkaitan dengan sungai, seperti mandi, cuci, kakus. Hal ini menggambarkan bagaimana sungai bukan sebagai hal yang vital dalam kehidupan.Sungai dianggap sebagai halaman belakang, karena itu muncul perilaku yang berkaitan dengan fungsi sungai yang dianggap sebagi backyard seperti kebiasaan membuang kotoran dan sampah lebih (Suganda, dkk, 2009).

Menurut deskripsi Kertodipoero (1963:10) tentang sungai dan pemukiman penduduk di pahuluan Kalimantan, rumahrumah berdiri di atas tiang, semuanya menghadap ke sungai, dan masing-masing rumah mempunyai batang-batang kayu (titian). Ia menyebut kampung-kampung yang berada di sepanjang tepian sungai sebagai sebuah "stasiun", yang menghubungkan satu kampung dengan kampung lainnya, dan setiap orang yang melewatinya bisa menyinggahinya.

Begitu menariknya kehidupan masyarakat di tepian sungai sehingga penulis merasa perlu untuk melihat fungsi sungai, khususnya bagi masyarakat yang tinggal di tepian Sungai Kuin di Kota Banjarmasin. Pertanyaan yang ingin dicari jawabannya adalah: Apakah sungai masih mempunyai fungsi bagi masyarakat di Kuin, meskipun pembangunan jalan darat telah memunculkan transportasi darat yang lebih modern, apakah sungai hanya semata-mata sebagai jalur transportasi, apakah masih terdapat fungsi-fungsi lainnya?

Dalam setiap kehidupannya manusia harus mampu menyesuaikan diri dengan lingkungan alam maupun sosial dan budaya. Proses penyesuaian diri manusia dilakukan melalui pembelajaran kultural (cultural learning), sehingga memungkinkan manusia untuk membentuk dan mengembangkan kehidupan dalam lingkungan ekologi tertentu.

Dengan berbagai kemampuan akal atau budinya, manusia telah mengembangkan berbagai macam sistem tindakan demi keperluan hidupnya. Hal tersebut berarti bahwa hampir seluruh tindakan manusia adalah "kebudayaan", karena hanya amat sedikit tindakan manusia dalam rangka kehidupan masyarakat yang tidak perlu dibiasakan dengan belajar.

Manusia akan selalu berhubungan dalam rangka memenuhi kebutuhan hidupnya, dengan berhubungan itu manusia menyampaikan maksud dan tujuan, sedangkan untuk mencapai keinginan itu harus diwujudkan melalui tindakan yang bersifat timbal balik. Kehidupan masyarakat dan kebudayaannya bersifat dinamis, sebab para warganya selalu mengadakan hubungan satu dengan lainnya baik dalam bentuk orang per orangan maupun dalam kelompok sosial. Sebelum hu- 
bungan-hubungan tersebut mempunyai bentuk yang konkrit, terlebih dulu akan dialami suatu proses ke arah bentuk konkrit yang sesuai dengan nilai-nilai sosial dan budaya dalam masyarakat. Dengan kata lain proses sosial diartikan sebagai pengaruh timbal balik diantara berbagai segi kehidupan bersama. Proses sosial dibedakan menjadi 2 bentuk

Proses asosiatif: mengarah kepada penggabungan dalam rangka mewujudkan nilai-nilai kebajikan. Proses disosiatif: mengarahkan pada terciptanya nilai-nilai negatif seperti pertentangan, perpecahan, permusuhan, kebencian dll (Soekanto, 2002).

Bentuk umum dari proses sosial adalah interaksi sosial, karena interaksi sosial merupakan syarat utama terjadinya aktivitas-aktivitas sosial (Soekanto, 2002:61). Interaksi sosial merupakan hubungan-hubungan sosial yang dinamis yang menyangkut hubungan antara orang perorangan, antara kelompokkelompok manusia, maupun antara orang perorangan dengan kelompok manusia. Suatu interaksi sosial tidak akan mungkin terjadi apabila tidak memenuhi dua syarat, yaitu: adanya kontak sosial dan adanya komunikasi Soekanto (2002:64).

Suatu kontak tidaklah semata-mata tergantung dari tindakan, tetapi juga tanggapan terhadap tindakan tersebut. Suatu kontak sosial dapat bersifat positif atau negatif, bisa mengarah pada suatu kerja sama atau pertentangan. Selain itu suatu kontak dapat bersifat primer atau sekunder, yaitu suatu hubungan langsung atau memerlukan suatu perantara. Komunikasi juga penting dalam interaksi sosial, karena seseorang perlu memberikan tafsiran pada perilaku orang lain, perasaanperasaan apa yang ingin disampaikan oleh orang tersebut. Namun dalam komunikasi tersebut kemungkinan akan terjadi berbagai macam penafsiran terhadap tingkah laku orang lain. Menurut Soekanto (2002:70), bentuk-bentuk interaksi sosial dapat berupa kerja sama (cooperation), persaingan (competition), dan pertentangan atau pertikaian (conflict).

Dalam konteks kehidupan masyarakat yang sangat dipengaruhi oleh budaya sungai, maka sungai bisa memainkan beragam fungsi. Pertama, sungai berfungsi sebagai jalur transportasi. Sebelum dibukanya jalur jalan darat, sungai merupakan satu-satunya jalur lalu lintas. Secara ekonomi, kondisi fisik lingkungan yang banyak terdapat sungai telah mendorong terjadinya aktivitas perekonomian melalui sungai. Subiyakto (2005:6) telah membuat deskripsi historis mengenai fungsi integratif pelayaran sungai terhadap perekonomian Kalimantan Selatan pada masa dahulu.

Menurutnya pelayaran sungai sebagai suatu cara perhubungan dan pengangkutan yang sangat diandalkan penduduknya. Hubungan antar tempat atau kontak antar penduduk hanya dapat berlangsung melalui cara melayari jalur-jalur air (waterways), seperti sungai, terusan, danau, perairan pantai, dan selat. Kelima bentuk jalur air ini merupakan unsur perairan sebagai bagian seutuhnya dari kondisi geografi fisik Kalimantan Selatan.

Sesuai dengan lingkungan alamnya maka masyarakat memilih berbagai mata pencaharian sesuai dengan keadaan alam sekitarnya. Dengan kondisi lingkungan perairan maka hampir seluruh aktivitas kehidupan masyarakat dijalankan di air, mulai dari pengangkutan komoditas, pemasaran, hingga mobilitas penduduk sehari-hari (Nuralang, 2004:91). Lancarnya transportasi telah mempercepat proses pendistribusian barang ke tempat yang dituju. Secara ekonomi, ketersediaan jaringan perhubungan telah memperlancar usaha pendistribusian barang sehingga dapat meningkatkan produksi dan konsumsi bagi masyarakat.

Upaya memperlancar transportasi, distribusi barang, dan kontak antar anggota masyarakat tidak semata-mata dilakukan melalui jalur sungai besar, tetapi juga dilakukan lewat sungai yang lebih kecil dengan anak-anak sungai dan kanal-kanalnya. Paling tidak masyarakat Banjar mengenal 3 (tiga) macam kanal, yaitu anjir, handil, dan saka (Subiyakto, 2005:61). Anjir/Antasan merupakan semacam saluran primer yang menghubungkan antara dua sungai, berfungsi untuk kepentingan umum, dengan titik berat sebagai saluran irigasi dan jalur transportasi. Handil/Tatah, semacam saluran yang bermuara ke sungai atau ke anjir, dibuat untuk menyalurkan air ke lahan per- 
tanian daerah daratan. Ukuran handil lebih kecil dibandingkan anjir, dan merupakan milik kelompok/bubuhan tertentu. Saka merupakan saluran tersier untuk menyalurkan air, yang biasanya diambilkan dari handil. Ukuran saka lebih kecil daripada handil, dan merupakan milik keluarga atau pribadi.

Schophuys (Humaidy, 2005:88) menyatakan bahwa kanal-kanal (anjir, handil, saka) tersebut betul-betul karya asli masyarakat Banjar yang disebutnya sebagai sistem irigasi orang Banjar, hasil pembelajaran sangat cerdas nenek moyang masyarakat Banjar terhadap lingkungannya yang sudah berabadabad lamanya. Ia menilai sistem irigasi itu sangat khas dalam rangka menjawab tantangan dari sebuah kota yang memiliki banyak sungai yang pasang surut. Kanal memiliki multi fungsi sebagai sarana pertanian, jalur pelayaran, pengangkutan barang, dan kebutuhan masyarakat akan air, mandi, cuci.

Lingkungan perairan tersebut juga menjadi media untuk sosialisasi diantara para warganya. Menurut Koentjaraningrat (1990:229) proses sosialisasi bersangkutan dengan proses belajar kebudayaan dalam hubungan dengan sistem sosialnya. Dalam proses tersebut seorang individu dari masa anak-anak hingga masa tua belajar polapola tindakan dalam interaksi dengan segala macam individu sekelilingnya yang menduduki beraneka macam peranan sosial yang mungkin ada dalam kehidupan sehari-hari. Selain sosialisasi, sebenarnya masih terdapat konsep -konsep penting lain yang berkautan dengan proses belajar kebudayaan oleh warga masyarakat yang bersangkutan, yaitu internalisasi dan enkulturasi.

Fungsi-fungsi dari sistem yang melingkupi sungai Kuin patut kiranya memaparkan terlebih dahulu pemikiran Merton mengenai analisis fungsional. Sekalipun Merton menganggap bahwa pendekatan fungional bukanlah suatu teori yang komprehensif dan terpadu, namun ini dapat dipakai sebagai stategi untuk analisa (Johnson, 1986). Dalam mengembangkan gagasannya ini, Marton menekankan tindakan-tindakan yang berulangkali atau yang baku yang berhubungan dengan bertahannya suatu sistem sosial dimana tindakan itu berakar (Johnson, 1986).
Merton membedakan fungsi manifest dan fungsi latent. Fungsi-fungsi manifest adalah konsekuensi-konsekuensi obyektif yang menyumbang pada penyesuaian terhadap sistem itu yang dimaksudkan dan diketahui oleh partisipan dalam sistem itu. Sedangkan fungsi-fungsi laten adalah yang tidak dimaksudkan dan tidak diketahui.

\section{METODE PENELITIAN}

Penelitian ini dilakukan dengan menggunakan metode deskriptif kualitatif. Sumber data dipilih secara purposive dan snowball sampling. Data yang diperoleh bersumber dari data primer dan data sekunder. Teknik pengumpulan data dilakukan dengan wawancara dan observasi.

\section{HASIL DAN PEMBAHASAN}

Daerah Kuin pada mulanya merupakan daerah titik awal perkembangan Kota Banjarmasin. Namun dalam perkembangannya, daerah Kuin hanyalah sebuah perkampungan yang terletak di pinggiran kota. Kuin hanya dikenal sebagai bagian masa lalu dengan peninggalan kuna, berupa situs makam Sultan Suriansyah sebagai pendiri Kesultanan Banjar dan masjid kuna Sultan Suriansyah. Selanjutnya Kuin dikenal karena lokasi Pasar Terapung yang terletak di muara Kuin Cerucuk.

Sebagaimana umumnya wilayah Kota Banjarmasin yang banyak dialiri sungai, demikian pula dengan daerah Kuin. Daerah ini dialiri oleh sebuah sungai, yaitu Sungai Pangeran atau Antasan Kuin, atau ada yang menyebut Sungai Kuin yang bermuara ke Sungai Barito. Untuk keperluan penulisan ini, selanjutnya disebut sebagai Sungai Kuin, yang melintasi wilayah Kelurahan Kuin Utara, Kuin Selatan, dan Kuin Cerucuk. Sungai Kuin sendiri juga mempunyai anak-anak cabang sungai, namun sekarang banyak yang hampir mati atau bahkan sudah mati. Oleh karena kondisi geografis berupa sungai, maka masyarakat Kuin juga akrab dengan kehidupan sungai.

Perumahan penduduk dibangun di sepanjang jalur sungai, baik yang berada di te- 
pian maupun di atas sungai. Rumah-rumah yang dibangun di tepian sungai menghadap ke sungai, namun yang dibangun di atas sungai justru membelakangi sungai. Pembangunan rumah-rumah di atas sungai telah menyebabkan alur sungai semakin menyempit. Akibat perkembangan jaman dan pertambahan penduduk, orang mulai membangun rumah jauh dari tepi sungai. Namun masyarakat tetap menentukan arah berpatokan pada posisi sungai. Arah yang makin menjauh dari sungai disebutnya arah ke darat, sedangkan arah yang mendekati ke sungai disebutnya arah ke laut. Sebagai contoh, apabila seseorang mau pergi menjauh dari sungai, ia disebut sedang bajalan ke darat, dan sebaliknya.

Pertambahan penduduk, pembangunan perumahan di wilayah darat, dan pembangunan jalan darat di kedua tepian sungai (Jl. Kuin Utara dan J1. Kuin Selatan) memang telah mengurangi aktivitas transportasi sungai. Namun demikian ternyata sungai tetap tidak ditinggalkan sama sekali oleh masyarakat yang tinggal di tepian Sungai Kuin. Secara umum fungsi sungai bagi masyarakat di tepian Sungai Kuin, antara lain adalah:

Sejak dulu sungai memegang peranan penting sebagai jalur transportasi di wilayah ini, sebab sungai-sungai yang melewati wilayah Kuin bermuara di Sungai Barito sebagai sungai terbesar di Kalimantan Selatan. Meskipun frekuensi transportasi sungai mulai berkurang, namun masih ada sebagian warga yang menggunakan jalur sungai. Setiap pagi bisa diamati transportasi tradisional sungai, seperti jukung dan klotok (taksi klotok) yang hilir mudik di sungai. Jukung adalah istilah yang digunakan oleh seluruh masyarakat dataran rendah Barito dan digunakan untuk semua jenis perahu/badan kapal.

Menurutnya terdapat 2 (dua) tipe dasar jukung, yaitu jukung sudur yang diolah dari pohon yang dibelah dua, dan jukung yang diolah dari satu batang pohon yang utuh. Jukung dan klotok tersebut mengangkut barang-barang dagangan dari hasil bumi, berupa sayur-sayuran, buah-buahan, ikan, d1l. Barang dagangan tersebut dibawa ke pasar terapung, dibawa ke pasar-pasar kecil yang ada di pinggir-pinggir sungai, atau dijajakan ke rumah-rumah di sepanjang sungai.
Pada sore hari bisa dilihat pemandangan menakjubkan, saat para penjaja pulang beriringan dengan menggunakan jukung. Mereka memakai topi lebar dari purun, dan jukungjukung yang tidak bermesin ditarik oleh sebuah jukung bermesin.

Selain itu pada setiap pagi bisa dilihat klotok-klotok dipakai untuk mengangkut para siswa yang akan menuju ke sekolahan masing-masing. Dalam konteks ini penggunaan klotok-klotok sama halnya transportasi sekolah seperti angkat/ bus sekolah. Menurut keterangan seorang siswa, ongkos naik klotok lebih murah dibandingkan dengan naik ojek. Sebenarnya telah ada taksi kota (angkot), namun ada taksi yang tidak melewati sekolah. Sebagai contoh, taksi hanya sampai di pangkalan taksi pasar apung, dan untuk menuju ke sekolah ia harus naik ojek atau jalan kaki namun jaraknya cukup jauh. Oleh karena itu siswa tersebut lebih suka naik klotok, turun di batang dekat sekolah, dan ongkosnya lebih murah. Pada saat pulang sekolah ia akan menggunakan jasa klotok lagi. Fungsi klotok sebagai transportasi yang efektif dan efisien itulah yang membuat klotok sebagai alat transportasi tradisonal di era modern ini belum tergantikan.

Pada pagi hari juga bisa dilihat anakanak TK yang diantar ibunya menyeberang dari satu sisi sungai ke sisi sungai yang lain. Mereka menyeberang menggunakan jasa jukung. Ongkos sekali menyeberang hanya lima ratus rupiah. Sebagai contoh anakanak dari Kuin Selatan yang bersekolah di TK Sultan Suriansyah di Kuin Utara. Untuk mempersingkat jarak, mereka menyeberang menggunakan jasa jukung. Demikian juga pada saat pulang, mereka juga menggunakan jasa jukung.

Ketiadaan jembatan yang menghubungkan daerah satu dengan lainnya membuat masyarakat tidak bisa beraktifitas secara leluasa. Anggaran yang besar yang harus dikeluarkan pemerintah untuk membuat jembatan untuk menghubungkan daerah pemukiman satu dengan lainnya juga tentu semakin sulit direalisasikan. Karena itu jukung-jukung penghubung daerah pemukiman satu dengan lainnya merupakan sebuah solusi. Contoh-contoh di atas merupakan 
contoh fungsi sungai sebagai jalur transportasi yang masih bisa disaksikan di Tepian Sungai Kuin.

Sudah dijelaskan bahwa sungai berfungsi sebagai jalur transportasi, untuk memudahkan mobilitas barang dan manusia. Distribusi barang dari satu tempat ke tempat lainnya berkaitan dengan aktivitas perekonomian penduduk. Pada pagi hari jukung dan klotok hilir mudik di Sungai Kuin untuk mengangkut barang dagangan, baik berupa hasil bumi, hasil perikanan, makanan, maupun barang-barang kelontong. Para pedagang menjajakan barang dagangannya di sepanjang sungai. Mereka berhenti di batang-batang rumah penduduk atau di batang-batang umum.

Alasan para pedagang memakai jukung dan klotok di Sungai Kuin dari pada menggunakan alat transportasi modern adalah karena kedua alat transportasi tradisional itu menyediakan kemudahan bagi para pedagang. Pertama, barang dagangan baik berupa hasil bumi, hasil perikanan, makanan, maupun barang-barang kelontong dapat diperjual belikan secara mudah karena pedagang dapat bertransaksi dengan pembeli di batang-batang. Kedua, antara klotok dan batang merupakan satu sistem terpadu yang memberikan banyak fungsi. Ketiga, transportasi ini masih belum tergantikan dengan transportasi darat yang lebih efektif dan efisien.

Suasana yang ramai ditemui pada saat penjual menghentikan dan menambatkan klotok atau jukungnya di batang umum. Tidak berapa lama penjual tersebut telah dikerubuti oleh para calon pembeli. Si penjual tetap berada di dalam jukung atau kelotoknya, sedangkan para pembeli berada di atas batang atau titian. Di tempat itulah terjadi traksaksi perdagangan. Para pembeli yang kebanyakan ibu-ibu membeli barang-barang untuk keperluan sehari-hari, seperti sayur, ikan, dan buah-buahan. Pada saat musim buah akan dilihat suatu pemandangan indah, saat jukung atau klotok melaju di atas sungai membawa rambutan atau jeruk dengan warna merah, hijau, kuning. Jika mereka membeli makanan/kue-kue maka para pembeli akan mengambil makanan tersebut dengan menggunakan alat yang bertangkai panjang.

Menurut penuturan seorang informan, ia lebih suka berbelanja sayur dan ikan ke batang, sebab tidak perlu mengeluarkan biaya, waktu, dan tenaga untuk pergi ke pasar. Selain itu harga barang-barang tersebut lebih murah, sebab biasanya penjual mengambil barang-barang dagangannya langsung dari petani, bahkan bisa berasal langsung dari tangan pertama (produsen). Oleh karena itu barang-barang dagangan, seperti ikan, sayur, dan buah masih dalam kondisi segar. Ikan yang mereka beli bisa langsung dibersihkan (disiangi) di batang, sehingga ketika dibawa pulang sudah dalam kondisi bersih. Ketika berada di batang itu, ia juga sambil membawa cucian. Artinya sambil mengerjakan pekerjaan mencuci, ia bisa sambil berbelanja untuk keperluan konsumsi sehari-hari. Rumah informan itu berada di darat, di sebuah gang.

Selain dari pedagang keliling, aktivitas ekonomi juga dijalani oleh para warga yang mempunyai rumah di atas sungai. Rumah yang dibangun di atas sungai, banyak yang menghadap dua arah yaitu arah sungai dan arah darat. Mereka mempunyai dua beranda, yaitu beranda depan yang menghadap jalan darat dan beranda belakang yang menghadap sungai. Namun banyak juga rumah yang dibangun menghadap ke jalan darat, sedangkan bagian belakang dijadikan sebagai dapur dan jamban keluarga. Bagi rumah yang mempunyai dua beranda, banyak yang memanfaatkan beranda belakang sebagai kios. Mereka membuka warung yang menjual makanan, barang-barang kelontong, maupun bensin dan minyak tanah. Bahkan ada warung makan yang sengaja dibangun menghadap sungai, dengan kata lain sungai dijadikan pemandangan terbuka oleh warung makan tersebut.

Warung-warung ini melayani para pembeli yang naik jukung atau klotok. Bahkan klotok atau perahu bermesin lainnya banyak yang singgah ke warung-warung tersebut untuk mengisi bensin. Saat klotok mengisi bensin, para penumpang bisa naik ke warung untuk minum teh, makan kue, atau makan nasi. Dengan demikian sungai 
sebagai jalur transportasi juga memberikan efek positif bagi para warga yang tinggal di atas sungai, yaitu efek ekonomis dan juga sosial. Efek sosial berupa interaksi diantara para warga dan interaksi diantara para penjual dan pembeli.

Sungai-sungai di wilayah ini sejak lama telah memegang peranan penting dalam kontak untuk berbagai kepentingan. Bukti dari adanya kontak ini adalah ditemukannya situs kuna di tepian Sungai Kuin. Sampai saat ini sungai masih memainkan peranan penting dalam interaksi antar warga masyarakat, meskipun telah berkembang permukiman penduduk yang dibangun jauh dari tepian sungai. Sebagai contoh, informasi yang diberikan oleh seorang infoman, meskipun rumah informan di darat sudah dilengkapi dengan kamar mandi dengan fasilitas air dari PDAM, namun informan tersebut lebih suka mandi ke batang/sungai.

Alasan masyarakat lebih senang mandi di sungai karena adanya rasa lebih puas, bisa sambil bakunyung (berenang), dan bisa ketemu dengan tetangga lainnya. Artinya sambil mandi di sungai, maka ia bisa berinteraksi dengan para tetangga yang sama-sama sedang mandi di sungai. Banyak hal yang mereka bicarakan, mulai dari hal-hal yang ringan sampai ke hal-hal yang serius.

Aktivitas warga, yang tinggal di atas sungai, di pinggir sungai, atau yang agak jauh dari sungai, telah dimulai sejak subuh. Ada diantara mereka yang hanya mandi dan mencuci, atau memulai aktivitas ekonomi. Pada pagi hari banyak dijumpai warga masyarakat, baik laki-laki, perempuan, tua, muda, maupun anak-anak yang mandi dan mencuci di sungai. Ada saja yang dipandirakan (dibicarakan) pada aktivitas tersebut. Memang pada waktu pagi itulah banyak kesempatan untuk ngrumpi, sambil menunggu datangnya jukung penjual sayur dan ikan. Ketika matahari semakin tinggi maka aktivitas di tepian sungai berangsur sepi.

Pada sore hari aktivitas di tepian sungai dimulai lagi, yaitu saat warga mandi di sungai. Pada sore hari banyak ditemui anak-anak yang mandi sambil bermain-main di sungai. Anak-anak tersebut umumnya mahir berenang dan menyelam. Sambil mandi, mereka bersenda gurau, keceriaan khas anak-anak. Kadang-kadang terlihat anak-anak yang bermain jukung, atau balapan berenang menyeberangi sungai. Selain itu juga dapat ditemui para pemancing yang berdiri di atas jembatan Pangeran, atau duduk-duduk di tepi sungai. Sambil memancing, mereka mengobrol tentang berbagai hal. Selepas maghrib sering ditemui para remaja yang kumpul-kumpul di jembatan Pangeran. Pada saat malam libur, jumlah remaja yang kumpul-kumpul bertambah banyak.

Dari berbagai aktivitas warga di tepian sungai, ada seorang informan perempuan yang mengaku bertemu jodoh di batang sungai. Mereka berdua sering bertemu di batang, akhirnya terjadi kontak dan komunikasi diantara mereka. Pada akhirnya keduanya menikah. Selain sebagai media interaksi, tepian sungai juga berfungsi untuk media sosialisasi yaitu suatu proses belajar kebudayaan oleh anggota masyarakat.

Dari sekian banyak aspek kehidupan berorientasi sungai, terdapat satu aspek budaya nonmateriil masyarakat Kuin, tentang totemisme yaitu kepercayaan bahwa wilayahnya dijaga oleh seekor buaya putih. Buaya ini diyakini bersemayam di Sungai Pangeran/Sungai Kuin, dan diyakini sebagai buaya keramat. Oleh karena dianggap keramat, maka pada waktu-waktu tertentu dilaksanakan ritual yang disebut malabuh. Upacara malabuh, yakni memberi sesaji kepada buaya, biasanya dilaksanakan di depan Masjid Sultan Suriansyah. Mereka percaya bahwa buaya itu akan muncul apabila menuntut diberi sesaji, atau sebagai isyarat akan datangnya peristiwa besar, atau berkaitan dengan keadaan di lingkungan daerah Kuin (Subiyakto, 2005:24). Mitos tentang buaya ini masih tetap hidup di kalangan masyarakat Kuin, sebab mitos ini lahir dari proses berpikir dan bertindak masyarakatnya terhadap lingkungan dan kondisi sosial.

Keseluruhan fungsi-fungsi sungai Kuin kiranya dapat dikaji dari teori fungsi yang dikemukakan oleh Merton. Masyarakat di sepanjang sungai Kuin memanfaatkan sungai dalam banyak hal, karena itu sungai seperti memiliki banyak fungsi bagai masyarakat. Tata kelola yang dikembangkan melalui 
gagasan-gagasan yang lahir berdasarkan harmonisasi hubungan yang ingin diciptakan masyarakat dengan masyarakat maupun masyarakat dengan alam telah melahirkan sebuah sistem budaya sungai Kuin.

Sistem ini berkaitan dengan bagaimana masyarakat membentuk pola yang saling berhubungan dari aspek sosial, budaya, ekonomi, mobilitas dan seterusnya. Seperti halnya penempatan batang atau titin adalah bagian yang tidak bisa terpisahkan dari sistem itu karena ia akan berhubungan dengan banyak hal seperti aktivitas pada aspek sosial, ekonomi maupun lainnya. Sekalipun jalan darat telah ada, namun fungsi jalan belum melahirkan konsekuensi-konsekuensi berupa sistem.

Penempatan ruang depan yang menghadap sungai bagi masyarakat yang tinggal di sepanjang sungai mencerminkan bahwa sungai merupakan bagian penting dalam kehidupan masyarakat sungai terkait dengan banyak aktivitas dari adanya ruang itu. Ruang ini menyediakan tempat untuk melakukan transaksi ekonomi, bisa juga digunakan untuk tempat mereka memulai aktivitas keluar rumah seperti berangkat ke sekolah. Sungai melahirkan fungsi-fungsi yang diciptakan masyarakat dari konsekuensi-konsekuensi untuk sistem sosial yang dibangun.

Merton dalam analisanya mengenai fungsi mengatakan bahwa tindakan-tindakan yang berulangkali atau yang baku berhubungan dengan bertahannya suatu sistem sosial dimana tindakan itu berakar (Johnson, 1986). Inilah kondisi yang terjadi pada masyarakat tepi sungai Kuin. Jalan darat yang telah disediakan belum mampu melahirkan tindakan-tindakan yang dilakukan berulang kali sehingga membentuk satu hubungan dengan aspek lainnya yang pada akhirnya mewujud dalam sebuah sistem. Namun hal ini berbeda dengan bagaimana peranan sungai yang telah banyak membentuk hubungan seperti sungai berfungsi sebagai jalur transportasi, maka dia berhubungan dengan fungsi lain seperti fungsi ekonomi dan fungsi interaksi dan sosialisasi.

$\mathrm{Hal}$ inilah yang dikatakan sebagai sistem, maka ketika alat transportasi tradisional seperti jukung dan klotok-klotok tidak beroperai maka akan mengganggu yang lainnya. Begitu pula ketika sungai dalam kondisi yang membahayakan misalnya karena debit air yang banyak serta arus deras pasca hujan tentu ini akan berpengaruh terhadap aspek lainnya pula. Analisa Merton selanjutnya adalah membedakan fungsi manifest dan fungsi latent. Fungsi-fungsi manifest adalah konsekuensi-konsekuensi obyektif yang menyumbang pada penyesuaian terhadap sistem itu yang dimaksudkan dan diketahui oleh partisipan dalam sistem itu. Sedangkan fungsi-fungsi laten adalah yang tidak dimaksudkan dan tidak diketahui.

Fungsi yang diemban oleh sungai Kuin seperti fungsi transportasi, fungsi sarana ekonomi dan fungsi interaksi serta sosialisasi merupan bentuk dari fungsi manifest sungai Kui itu sendiri. Secara jelas konsekuensikonsekuensi obyektif dari sungai itu secara sadar diketahui oleh karena itu maka fungsi sungai Kuin tadi adalah bagian dari fungsi manifest. Sedangkan fungsi laten dari sungai Kuin dengan segala aktivitas di atas sebagai ruang publik pembelajaran kultural (cultural learning), sehingga memungkinkan manusia untuk membentuk dan mengembangkan kehidupan sosial dalam lingkungan ekologi tertentu.

\section{SIMPULAN}

Sungai bagi masyarakat di Tepian Sungai Kuin masih memegang peranan yang cukup penting dalam berbagai segi kehidupan. Sungai tidak hanya semata-mata berfungsi sebagai jalur transportasi, tetapi sungai juga berperan dalam aktivitas perekonomian. Selain itu masih banyak warga masyarakat yang memanfaatkan sungai untuk keperluan mandi dan cuci. Sambil melakukan aktivitas tersebut, warga masyarakat bisa melakukan interaksi untuk berbagai tujuan. Selain sebagai media interaksi, tepian sungai juga dijadikan sebagai sarana sosialisasi untuk belajar kebudayaan masyarakatnya. Sungai masih menempati kedudukan yang cukup penting dalam kehidupan masyarakat, yang memiliki fungsi yang beragam, mulai dari fungsi transportasi hingga fungsi sosial dan ekonomi masyarakat. Fungsi sungai Kuin se- 
perti itu menegaskan fungsi manifest, tetapi yang tidak kalah penting fungsi sungai Kuin menjadi ruang publik pembelajaran kultural (cultural learning) masyarakat budaya sungai dengan segala ide aktivitas maupun artefak yang dihasilkan darinya. Inilah fungsi laten sungai Kuin dalam proses sosial manusia di atasnya.

\section{DAFTAR PUSTAKA}

Humaidy, 2005, "Revitalisasi Sungai Di Kota Seribu Sungai", dalam Kandil, Edisi 9, Tahun III, MeiJuli 2005

Johnson, Doyle Paul. 1986. Teori Sosiologi Klasik dan Modern. Jakarta: Gramedia

Kertodipoero, Sarwoto, 1963. Kaharingan : Religi Dan Penghidupan Di Pahuluan Kalimantan. Penerbit Sumur Bandung.

Nuralang, Andi, 2004, "Sungai Sebagai Jalur Utama Aktivitas Perekonomian Masyarakat Di Ka- limantan Selatan", dalam Gunadi Kasnowihardjo, 2004. Sungai Dan Kehidupan Masyarakat Di Kalimantan. Banjarbaru : Ikatan Ahli Arkeologi Indonesia Komda Kalimantan.

Nurdiana, T. 2010. Sunat Perempuan Pada Masyarakat Kota Banjarmasin. Jurnal Komunitas, 2 (2): 50-58

Soerjono Soekanto, 2002. Sosiologi Suatu Pengantar. Jakarta : Raja Grafindo Persada.

Subiyakto, Bambang, 2005, "Arti Penting Perairan Bagi Transportasi Masyarakat Banjar", dalam Kandil, Edisi 9, Tahun III, Mei-Juli 2005.

Subiyakto, Bambang, 2005, "Fungsi Integratif Pelayaran Sungai Terhadap Perekonomian Kalimantan Selatan Pada Masa Dahulu", dalam Kandil, Edisi 9, Tahun III, Mei-Juli 2005

Subiyakto, Bambang, 2005, "Totemisme, Mitos Bagaduhan Buhaya Pada Masyarakat Banjar", dalam Kandil, Edisi 9, Tahun III, Mei-Juli 2005

Suganda, Emirhadi. Dkk. 2009. Pengelolaan Lingkungan dan Kondisi Masyarakat Pada Wilayah Hilir Sungai. Jurnal Makara Sosial Humaniora, 13 (32): $143-153$ 